\title{
Usulan Perbaikan Proses Pelayanan Loading dan Unloading Kapal di Dermaga Curah Cair PT. X dengan Pendekatan Simulasi
}

\author{
Misra Hartati ${ }^{1}$, Irhamzah², Fitra Lestari Norhiza ${ }^{3}$, Tengku Nurainun ${ }^{4}$ \\ 1,2,3,4) Fakultas Sains dan Teknologi, Jurusan Teknik Industri, UIN Suska Riau \\ JI. HR. Soebrantas No. 155, Simpang Baru, Panam, Pekanbaru, 28293. \\ Email: misrahartati@gmail.com ${ }^{1}$, irhamzah4@gmail.com²
}

\begin{abstract}
Abstrack
Indonesia as one of the biggest archipelagic countries, sees the potential for the need for ports as an inter-island logistics sector. Ports in Indonesia are managed by PT. Indonesian Port, one of the branches of PT. Pelindo is PT. $X$ which has liquid bulk stores specifically for CPO loading and unloading. The problem that occurs is the increase in loading and unloading service time that has exceeded the set resting time, which results in the length of the waiting time for the ship in the pool. So that it will have an impact on the quality of CPO, which causes an increase in the levels of free fatty acids in CPO. Because it is proposed to improve the process of loading and unloading CPO services to minimize queues and reduce ship waiting times. Simulation is completed with ExtandSim software. As for the selected scenario, namely the second alternative scenario showing an increase in service on each pier, the average ship input is 64 ships and the average output is 62 ships, more optimal than conceptual conditions, the proposed calculation of investment costs is the addition of a pipeline of 104,244.00 US $\$$.
\end{abstract}

Keywords: Extendsim, Port Of Liquid Bulk, CPO, Descrette Event Simulation

\begin{abstract}
Abstrak
Indonesia sebagai salah satu negara kepulaun terbesar di dunia, melihat potensi tersebut diperlukannya pelabuhan sebagai sektor logistik antar pulau. Pelabuhan di indonesia di kelola oleh PT. Pelabuhan Indonesia, salah satu cabang PT. Pelindo adalah PT. X yang memiliki dernaga curah cair khusus bongkar muat CPO. Permasalahan yang terjadi adalah meningkatnya waktu proses pelayanan bongkar muat yang melebihi waktu sandar yang telah ditetapkan, yang berakibat lamanya waktu tunggu kapal di kolam labuh. Sehingga akan berdampak pada kualitas CPO, yang menyebabkan naiknya kadar asam lemak bebas pada CPO. Oleh karena dilakukan usulan perbaikan proses pelayanan bongkar dan muat CPO untuk meminimasi antrian serta memperkecil waktu tunggu kapal. Simulasi diselesaikan dengan software ExtandSim. Adapun skenario terpilih yaitu skenario alternatif kedua menperlihatkan peningkatan pelayanan pada setiap dermaga, nilia rata-rata input kapal adalah 64 kapal dan rata-rata output 62 kapal, lebih optimal dari kondisi konseptual, Usulan perhitungan biaya investasi penambahan jalur pipa adalah 104.244,00 US\$.
\end{abstract}

Kata Kunci: ExtendSim, Pelabuhan Curah Cair, CPO, Simulasi Distrik

\section{Pendahuluan}

Indonesia sebagai salah satu negara kepulaun terbesar dengan luas perbandingan laut dan daratan kurang lebih dua pertiga dari wilayah teritori indonesia. Melihat potensi wilayah Indonesia yang sangat besar yang berbentuk kepulauan sehingga dibutuhkan peran sektor logistik. Sehingga diperlukannya pelabuhan, pelabuhan merupakan suatu tempat yang terdiri atas daratan atau perairan dengan batas-batas tertentu sebagai tempat kegiatan pemerintahan dan kegiatan pengusahaan yang dipergunakan sebagai tempat kapal bersandar. Pelabuhan di indonesia di kelola oleh badan usaha milik negara, yaitu PT. Pelabuhan Indonesia (Pelindo). Salah satu cabang PT. Pelindo adalah PT. X merupakan salah satu pelabuhan utama di Propinsi $X$.

PT. $X$ mempunyai dermaga $B$ sebagai dermaga curah cair. pada dermaga $B$ yang menjadi perhatian dalam proses pelayananan dermaga, karena pada dermaga $B$ memiliki 
tingkat kujungan kapal yang terus meningkat setiap tahunnya berikut merupakan data kunjungan kapal di dermaga B.

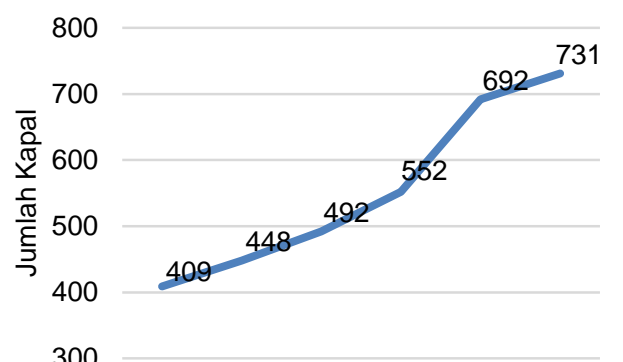

201220132014201520162017

Kujungan Kapal

\section{Gambar 1 Kunjungan Kapal ke Dermaga B}

Dermaga B merupakan salah satu dermaga yang dimiliki oleh PT. X, yang melayani kegiatan bongkar muat komuditas jenis curah cair yang di dominasi oleh Crude Palm Oil (CPO). Permintaan dan kebutuhan Crude Palm Oil (CPO) saat ini mengalami peningkatan setiap tahunnya, dari data PT. X khususnya di dermaga $\mathrm{B}$ memperlihatkan kenaikan akan bongkar muat $\mathrm{CPO}$, sebagai berikut:

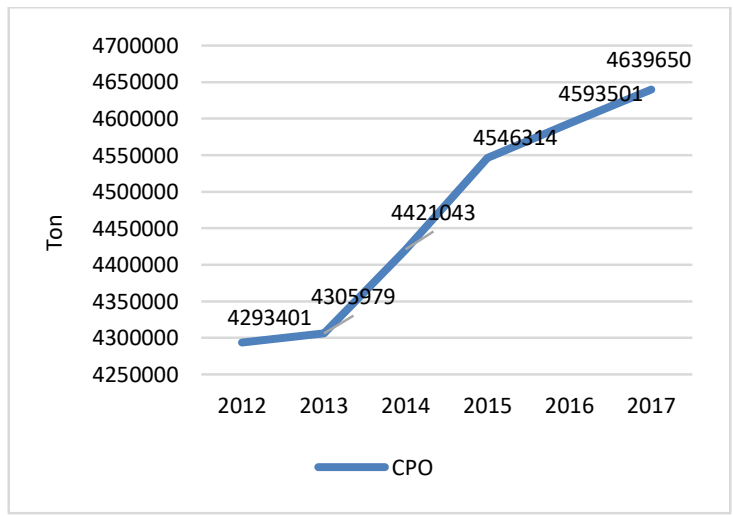

Gambar 2 Jumlah Bongkar Muat CPO

Berdasarkan Gambar 1 dan Gambar 2 dapat dilihat bahwa kunjungan kapal dan permintaan akan kebutuhanCPO di dermaga $B$ mengalami peningkatan setiap tahunnya. Berdasaarkan hal tersebut tentunya harus didukung dengan utilitas pelabuhan yang memadai. Kondisi saat ini proses pelayanan di dermaga B masih tergolong lama, pada proses pelayanan bongkar muat di pelabuhan sering kali melebihi prediksi waktu pelayanan yang telah ditetapkan, sehingga menyebabkan antrian kapal dan meningkatnya waiting time kapal saat berlabuh. Berikut ini data waktu kedatangan kapal di dermaga $B$.
Tabel 1. Data Waktu Kedatangan Kapal

\begin{tabular}{|c|c|c|c|c|}
\hline $\begin{array}{c}\text { Jenis } \\
\text { Kapal }\end{array}$ & $\begin{array}{c}\text { Interval } \\
\text { Kedatangan } \\
\text { Kapal } \\
\text { (Jam) }\end{array}$ & $\begin{array}{c}\text { Loading } \\
\text { Time }\end{array}$ & $\begin{array}{c}\text { Prediksi } \\
\text { Waktu } \\
\text { loading } \\
\text { Kapal } \\
\text { (Jam) }\end{array}$ & $\begin{array}{c}\text { Time to } \\
\text { berth }\end{array}$ \\
\hline 1 & 10 & 72 & 54 & 119 \\
\hline 2 & 8 & 76 & 54 & 118 \\
\hline 3 & 8 & 74 & 54 & 120 \\
\hline 4 & 9 & 75 & 54 & 115 \\
\hline 5 & 11 & 78 & 54 & 123 \\
\hline 6 & 8 & 71 & 54 & 120 \\
\hline 7 & 8 & 81 & 54 & 110 \\
\hline 8 & 9 & 70 & 54 & 125 \\
\hline 9 & 7 & 76 & 54 & 128 \\
\hline 10 & 8 & 73 & 54 & 125 \\
\hline
\end{tabular}

Berdasarkan Tabel 1 dapat dilihat bahwa kapal yang melakukan proses bongkar muat melebihi prediksi waktu yang telah ditetapkan. lama waktu bongkar muat dan tingginya waiting time yang terjadi di pelabuhan PT. X, akan menyebabkan kerugian bagi perusahaan pengguna jasa pelabuhan. Adapun kerugian yang dialami oleh perusahaan pengguna jasa yaitu meningkatnya kadar Asam Lemak Bebas pada Crude Palm Oil (CPO), berikut ini merupakan kenaikan kadar Asam Lemak Bebas pada CPO yang pada setiap palka kapal adalah:

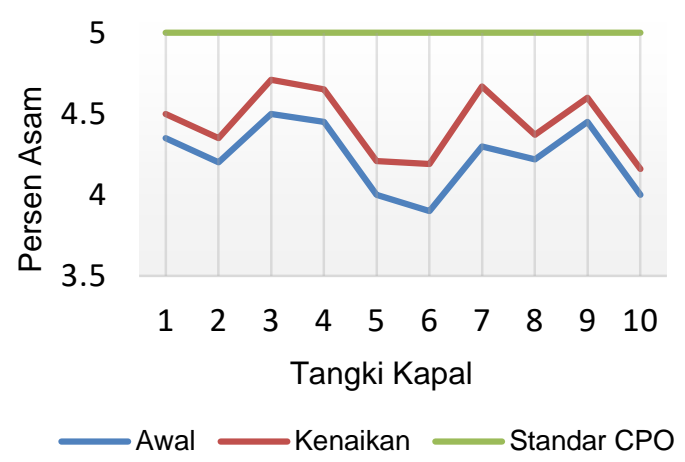

Gambar 3 Kenaikan Kadar Asam Pada CPO

Berdasarkan Gambar 3 dapat dilihat bahwa kadar Asam Lemak Bebas CPO pada setiap palka kapal mengalami kenaikan. Kenaikan kadar Asam Lemak Bebas CPO dan turunan disebabkan oleh lamanya proses bongkar muat CPO. Sehingga terjadinya kenaikan kadar Asam Lemak Bebas CPO pada tangki kapal. Menurut Marunduri, 2009 yaitu selama proses penyimpanan CPO di dalam tangki maka terjadi peningkatan kadar asam lemak bebas (ALB) yang disebabkan terjadinya proses autokatalitik yang dipercepat oleh suhu panas.

Melihat permasalahan tersebut PT. X sebaiknya harus meningkatkan proses pelayanan bongkar muat pada dermaga curah 
cair. Upaya peningkatan proses bongkar muat harus di dukung dengan fasilitas dan peralatan yang memadai. Oleh karena itu perlu dilakukanya perbaikan pelayanan pelabuhan adalah dengan menggunakan teori antrian.

Antrian adalah suatu garis tunggu (satuan) yang memerlukan layanan dari satu atau lebih pelayan (fasilitas layanan). Antrian terjadi karena tingkat kedatangan lebih besar dari pada kemampuan untuk melayani pada suatu waktu tertentu dan tidak terjadi sepanjang waktu (Ahmad, 2016). Aturan dalam pelayanan penyandaran kapal tetap berdasarkan pada disiplin antrian yang umum yaitu first come first served.

Penyelesaian teori antrian diperlukan suatu pemodelan dan simulasi untuk menganalisa sistem sehingga dapat diketahui bagaimana tingkah laku suatu model. Metode simulasi banyak digunakan untuk menyelesaikan segala macam permasalahan proses perindustrian, maupun pada proses pengiriman. Menurut Rizal, (2015), keuntungan dalam menggunakan metode simulasi adalah percobaan dengan skenario yang berbeda dapat dilakukan tanpa mempengaruhi kinerja operasional harian. Discrete Event Simulation digunakan untuk memodelkan sistem bongkar muat komoditas curah cair sehingga dapat melihat arus pelayanan bongkar muat di dermaga curah cair PT. $X$ tersebut. Simulasi ini kemudian di buat skenario-skenario perbaikan, serta di harapkan mampu mambantu dalam pengambilan keputusan dalam meningkatkan pelayanan bongkar muat di pelabuhan.

\section{Metode Penelitian}

Adapun metode penelitian ini adalah sebagai berikut:

\section{Merancang Model Konseptual}

Perancangan model dilakukan dengan menggunakan Activity Cycle Diagram (ACD) sebagai upaya menerjemahkan kompleksitas sistem nyata ke dalam model yang di sesuaikan dengan rumusan masalah yang ingin diselesaikan dan tujuan dilakukan permodelan. Pengolahan data ACD adalah bahasa grafik atau gambar yang memodelkan sistem dengan menunjukkan hubungan interaksi antar elemen dengan perubahan secara distrik terhadap waktu. Activity Cycle Diagram (ACD) berguna untuk memperhatikan keterkaitan antar kegiatan, melihat berapa banyak entity dalam sistem yang kita amati

\section{Menentukan Distribusi Data}

Dimulai dengan menentukan distribusi dari setiap input proses model sehingga dapat menggambarkan kejadian nyata.

\section{Perancangan Model Software}

Perancangan model dan running model simulasi menggunakan software Extandsim, seeai dengan model konseptual. Software Ekstandsim ini mampu membangun model Discrete-Event Simulation.

\section{Penentuan Rpelikasi}

Menentukan jumlah replikasi yang dijalankan pada model simulasi melalui perhitungan rumus, penentuan jumlah replikasi (2-14) dengan kepercayaan sebesar $95 \%$.

\section{Verikasi}

Verifikasi dilakukan untuk memastikan bahwa model simulasi memiliki logika proses yang sama dengan model konseptual yang mewakili sistem nyata.

\section{Menjalankan Model Simulasi}

Simulasi harus terlebih dahulu dijalankan agar memperoleh output. Model ini dijalankan sesuai dengan parameter pada sistem bongkar muat pada pelabuhan.

\section{Validasi}

Hasil uji coba program diteliti kembali untuk mendeteksi apakah ada kesalahan dalam model dan jika perlu ada modifikasi.

\section{Melakukan Skenario Perbaikan}

Dalam menyusun skenario perbaikan pasti ditemukannya kondisi dimana nilai utilitas atau peralatan yang digunakan melebihi waktu pelayanan yang telah ditetapkan.

\section{Skenario Terpilih}

Setelah melakukan skenario perbaikan yang akan dipilih akan diketahui kondisi sistem pengamatan pada saat ini. maka didapatkan jumlah in, out, waiting time dan utilization yang lebih optimal dari proses pelayanan bongkar muat pada kondisi eksisting. 


\section{Hasil dan Pembahasan}

\section{Perancangan Model ACD}

Pemodelan simulasi dengan strategi threephase ini dilakukan dengan Activity Cycle Diagram (ACD), yang terdiri dari kotak untuk representasi kegiatan, bulatan untuk representasi tempat menunggu, dan panah sebagai aliran sumber daya (Ihsan, 2015). Pembuatan model konseptual yang dilakukan sebelum merancang suatu model simulasi sebelum di masukkan kedalam sofware Extandsim. Activity Cyle Diagram (ACD) Pemuatan

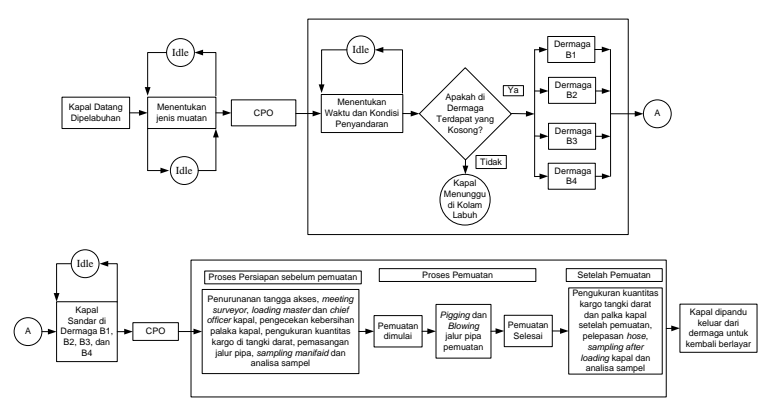

Gambar 4 Activity Cycle Diagram Proses Pemuatan
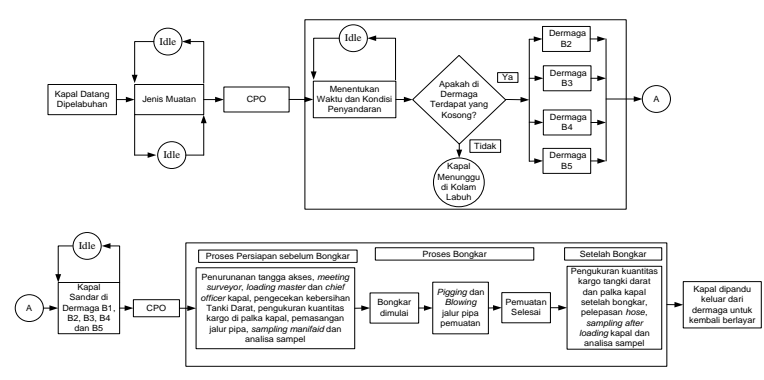

Gambar 5 Activity Cycle Diagram Proses Bongkaran

\section{Penentuan Distribusi}

Hasil pengujian distribusi dari data waktu pemuatan ditampilkan pada Tabel 2 sebagai berikut:

Tabel 2. Distribusi Data

\begin{tabular}{|l|l|l|}
\hline No & \multicolumn{1}{|c|}{ Jenis Kegiatan } & \multicolumn{1}{c|}{ Distribusi } \\
\hline 1 & $\begin{array}{l}\text { Waktu antar } \\
\text { kedatangan kapal }\end{array}$ & Normal \\
\hline 2 & $\begin{array}{l}\text { Waktu persiapan } \\
\text { pemuatan }\end{array}$ & Beta \\
\hline 3 & Waktu pemuatan & Triangular \\
\hline 4 & $\begin{array}{l}\text { Waktu tunggu kapal } \\
\text { sebelum berlayar }\end{array}$ & Triangular \\
\hline
\end{tabular}

\section{Perancangan Model Awal ExtendSim}

Model konseptual yang dirancang dengan menggunakan Sofware Extandsim berdasarkan model konseptul yang telah dibuat dengan Activity Caycle Diagram. Berikut ini merupakan gambaran dari simulasi dengan menggunakan sofware Extandsim yang ada pada sistem antrian yang pada dermaga Curah Cair PT. X sebagai berikut:

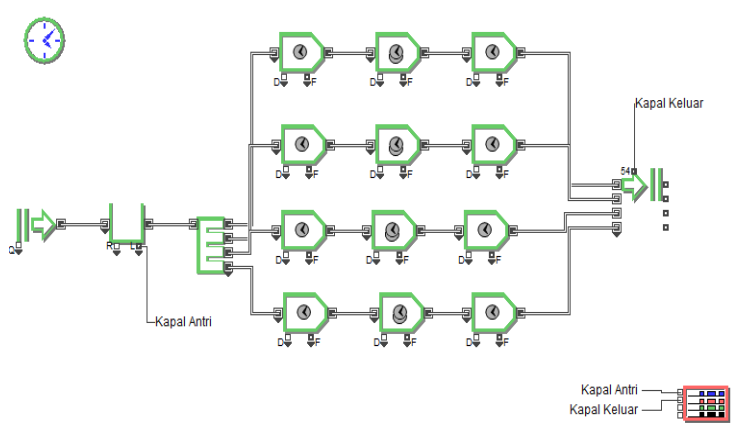

Gambar 6 Model Awal

\section{Penentuan Jumlah Replikasi}

Penentuan jumlah replikasi merupakan hal yang sangat penting dalam menjalankan simulasi. Dikarenakan jumlah replikasi atau perulangan dapat menentukan kualitas dari simulasi tersebut. Untuk mendapatkan jumlah replikasi yang di butuhkan, maka diperlukan run sejumlah 10 replikasi percobaan. Adapun perhitungan untuk mengetahui banyaknya replikasi yang dibutuhkan adalah sebagai berikut:

Dengan interval kepercayaan sebesar 95\% maka perhitunganya adalah Walpole, (1992) :

$$
\begin{aligned}
\mathrm{n} & =10 \\
\mathrm{n}-1 & =9 \\
\mathrm{a} & =0,05 \\
\mathrm{hw} & =\frac{\left(\mathrm{t}_{\mathrm{n}}-1 \cdot \frac{\alpha}{2}\right) \times \mathrm{S}}{\sqrt{\mathrm{n}}} \\
& =\frac{2,262 \times 0,85}{\sqrt{10}} \\
& =0,61
\end{aligned}
$$

$$
\begin{aligned}
n^{\prime} & =\left[\frac{\left(z_{\frac{\alpha}{2}}^{\alpha}\right) S}{h w}\right]^{2} \\
& =\left[\frac{1,96 \times 0,85}{0,61}\right]^{2} \\
& =7,49 \approx 8
\end{aligned}
$$

Dari perhitungan yang telah dilakukan diperoleh jumlah replikasi yang dibutuhkan sebanyak 8 kali. 


\section{Validasi Model}

Validasi merupakan membandingkan model simulasi dengan real system. Model valid apabila hasil perbandingan menunjukkan bahwa (model dan real system) tidak berbeda secara signifikan (Banks, 2005).

Tabel 3. Validasi Model

\begin{tabular}{|c|c|c|c|}
\hline $\begin{array}{c}\text { Replikasi } \\
\text { Ke- }\end{array}$ & $\begin{array}{c}\text { Output } \\
\text { Simulasi }\end{array}$ & $\begin{array}{c}\text { Output } \\
\text { Nyata }\end{array}$ & $\begin{array}{c}\text { Troughtput } \\
\text { Difference }\end{array}$ \\
\hline 1 & 32 & 39 & -3 \\
\hline 2 & 34 & 35 & -1 \\
\hline 3 & 34 & 35 & -1 \\
\hline 4 & 33 & 31 & 3 \\
\hline 5 & 32 & 32 & 3 \\
\hline 6 & 34 & 38 & -3 \\
\hline 7 & 34 & 37 & -3 \\
\hline 8 & 34 & 40 & -4 \\
\hline $\begin{array}{c}\text { Rata- } \\
\text { Rata }\end{array}$ & $\mathbf{3 3 , 3 7}$ & $\mathbf{3 5 , 1 3}$ & $\mathbf{- 1 , 7 5}$ \\
\hline Variansi & $\mathbf{0 , 8 4}$ & $\mathbf{1 1 , 2 7}$ & $\mathbf{1 1 , 3 7}$ \\
\hline $\begin{array}{c}\text { Standar } \\
\text { Deviasi }\end{array}$ & $\mathbf{0 , 9 2}$ & $\mathbf{3 , 3 6}$ & $\mathbf{3 , 3 7}$ \\
\hline
\end{tabular}

Hipotesa:

Ho $: \mu_{1}-\mu_{2}=0$ atau tidak ada perbedaan yang signifikan antara output nyata dengan output simulasi.

$\mathrm{H} 1 \quad: \mu_{1}-\mu_{2} \neq 0$ atau terdapat perbedaan signifikan antara output nyata dengan output simulasi.

Dengan level signifikan $\alpha=0,05$. maka didapatkan sebagai berikut:

$$
\begin{aligned}
H w & =\frac{\left(t_{n}-1 \cdot \frac{\alpha}{2}\right) \times S}{\sqrt{n}} \\
& =\frac{2,365 \times 3,37}{\sqrt{8}} \\
& =2,81
\end{aligned}
$$

Sehingga nilai perbandingan reratanya pada interval adalah sebagai berikut:

$$
\begin{aligned}
& =\left[(\bar{X} 1-\bar{X} 2)-\mathrm{Hw} \leq \mu_{1}-\mu_{2} \leq(\bar{X} 1-\bar{X} 2)+\mathrm{Hw}\right] \\
& =\left[-1,75-2,81 \leq \mu_{1}-\mu_{2} \leq-1,75+2,81\right] \\
& =\left(-4,56 \leq \mu_{1}-\mu_{2} \leq 1,06\right)
\end{aligned}
$$

Berdasarkan hasil yang didapatkan bahwa nilai 0 berada pada rentang dari hasil tersebut, maka $\mathrm{H}_{0}$ dapat diterima. Dengan demikian dapat diambil kesimpulan tidak ada perbedaan signifikan antara output sistem dengan kondisi nyata output saat simulasi. Sehingga dapat dikatakan bahwa simulasi yang telah dirancang valid.

\section{Simulasi Kondisi Awal}

Setelah dilakukanya simulasi sebelumnya maka akan dapat diketahui kondisi sistem pengamatan pada saat ini. Berikut verifikasi hasil berdasarkan software extandsim:

Tabel 4. Hasil Simulasi Kondisi Awal

\begin{tabular}{|c|c|c|}
\hline $\begin{array}{c}\text { Replikasi } \\
\text { Ke- }\end{array}$ & $\begin{array}{c}\text { Jumlah } \\
\text { Output }\end{array}$ & $\begin{array}{c}\text { Jumlah } \\
\text { Input }\end{array}$ \\
\hline 1 & 32 & 65 \\
\hline 2 & 34 & 67 \\
\hline 3 & 34 & 64 \\
\hline 4 & 33 & 65 \\
\hline 5 & 32 & 65 \\
\hline 6 & 34 & 65 \\
\hline 7 & 34 & 64 \\
\hline 8 & 34 & 65 \\
\hline Total & 267 & 519 \\
\hline Rata-rata & 33,37 & 64,87 \\
\hline
\end{tabular}

Berdasarkan Tabel 4 Dapat dilihat bahwa jumlah input yang dihasilkan sebesar 519 dan output yang dihasilkan 267. Tentunya interval antara jumlah input dan jumlah output yang masih besar, sehingga masih banyaknya kapal yang mengantri di kolam labuh.

\section{Merancang Model Simulasi Perbaikan}

Membuat model simulasi usulan merupakan tahapan dalam menggambarkan suatu sistem berdasarkan usulan yang dirancang untuk dapat menghasilkan suatu output atau keluaran jumlah antrian kapal yang lebih banyak dan juga meminimumkan waktu antrian yang dapat menyebabkan terjadinya antrian kapal di kolam labuh semakin tinggi.

Simulasi kondisi usulan alternatif ini dilakukan dengan cara penambahan aktivitas loading point menjadi 2 kegiatan, dimana penambahan aktivitas pada setiap dermaga dilakukan dengan cara penambahan jalur pipa. Berikut ini merupakan model simulasi pada software Extandsim adalah sebagai berikut:

\section{Usulan Alternatif Pertama}

Perencangan alternatif pertama merupakan alternatif perancangan model simulasi yang pada model ini dilakukan penambahan 1 jalur pipa pada dermaga B3 dan B4, karena pada hasil simulasi konseptual di dermaga tersebut menunjukkan pelayanan yang lebih sedikit dari dari dermaga B1 dan B2. Berikut ini merupakan hasil simulasi dari usulan alternatif pertama: 
Tabel 5. Hasil Simulasi Alternatif Pertama

\begin{tabular}{|c|c|c|}
\hline $\begin{array}{c}\text { Replikasi } \\
\text { Ke- }\end{array}$ & $\begin{array}{c}\text { Jumlah } \\
\text { Input }\end{array}$ & $\begin{array}{c}\text { Jumlah } \\
\text { Output }\end{array}$ \\
\hline 1 & 64 & 33 \\
\hline 2 & 64 & 32 \\
\hline 3 & 64 & 33 \\
\hline 4 & 64 & 32 \\
\hline 5 & 65 & 36 \\
\hline 6 & 65 & 32 \\
\hline 7 & 64 & 33 \\
\hline 8 & 65 & 32 \\
\hline Total & 515 & 263 \\
\hline Rata-rata & 64,37 & 32,87 \\
\hline
\end{tabular}

Dari Tabel 5 Dapat dilihat bahwa jumlah output setelah dilakukannya perancangan model usulan alternatif pertama sebanyak 8 replikasi di peroleh nilai rata-rata output sebesar 32,87 kapal sedangkan input nya dengan rata-rata sebesar 64,37 kapal.

\section{Usulan Alternatif Kedua}

Usulan alternatif kedua ini dilakukan berdasarkan pada alternatif pertama masih belum tercapainya alternatif perbaikan yang akan di rancang. Model simulasi pada model ini dilakukan penambahan 1 jalur pipa pada dermaga B1 dan B2. Berikut ini merupakan hasil simulasi alternatif kedua:

Tabel 6. Simulasi Usulan Alternatif Kedua

\begin{tabular}{|c|c|c|}
\hline $\begin{array}{c}\text { Replikasi } \\
\text { Ke- }\end{array}$ & $\begin{array}{c}\text { Jumlah } \\
\text { Input }\end{array}$ & $\begin{array}{c}\text { Jumlah } \\
\text { Output }\end{array}$ \\
\hline 1 & 64 & 61 \\
\hline 2 & 62 & 60 \\
\hline 3 & 64 & 60 \\
\hline 4 & 66 & 62 \\
\hline 5 & 64 & 62 \\
\hline 6 & 64 & 62 \\
\hline 7 & 64 & 62 \\
\hline 8 & 64 & 60 \\
\hline Total & 512 & 489 \\
\hline Rata-rata & 64 & 61,12 \\
\hline
\end{tabular}

Dari Tabel 6 Dapat dilihat bahwa jumlah output setelah dilakukannya perancangan model usulan alternatif kedua sebanyak 8 replikasi di peroleh nilai rata-rata output sebesar 61,12 kapal sedangkan input nya dengan rata-rata sebesar 64 kapal. Berdasarkan hasil yang didapatkan pada alternatif kedua ini menunjukkan output atau kapal yang terlayani semakin banyak dan jumlah kapal yang mengantri di kolam labuh menjadi sedikit, sehingga tidak perlu dilakukannya untuk alternative perbaikan selanjutnya.

\section{Skenario Terpilih}

Setelah dilakukan peracangan model perbaikan maka dilakukan perbandingan antara model simulasi awal dengan model simulasi perbaikan. Adapaun skenario perbaikan yang dapat dikategorikan sebagai skenario terbaik ialah skenario yang menghasilkan output optimum. Penentuan skenario terbaik nantinya dapat menjadi usulan ataupun saran bagi perusahaan untuk dapat diterapkan. Berikut ini merupakan perbandingan hasil output simulasi awal dengan output simulasi model perbaikan adalah sebagai berikut:

Tabel 7. Perbandingan Output

\begin{tabular}{|c|c|c|}
\hline No & Nama Skenario & $\begin{array}{c}\text { Jumlah } \\
\text { Output }\end{array}$ \\
\hline 1 & Model Awal & 278 \\
\hline 2 & Alternatif Pertama & 263 \\
\hline 3 & Alternatif Kedua & 489 \\
\hline
\end{tabular}

Berdasarkan Tabel 7 dapat dilihat bahwa model awal menghasilkan output sebesar 278, kemudian pada alternatif pertama dengan penambahan jalur pipa pada dermaga B3 dan dermaga B4 menghasilkan jumlah output atau jumlah kapal yang terlayani yaitu 263 kapal. Sedangkan pada skenario kedua dilakukan penambahan jalur pipa lagi di dermaga B1 dan B2 menghasilkan jumlah output atau jumlah kapal yang terlayani yaitu 489 kapal, berdasarkan hal tersebut menunjukkan bahwa pada model simulasi alternatif kedua telah memiliki tingkat pelayanan yang telah optimal, yang menghasilkan output atau kapal yang telah dilayani lebih banyak dari model awal dan model alternatif pertama. Sehingga pada model alternatif kedua dapat digunakan sebagai usulan perbaikan untuk meningkatkan pelayanan di dermaga, serta meminimasi antrian kapal dan menurunkan waktu tunggu kapal di kolam labuh PT. X.

\section{Perhitungan Biaya Investasi}

Perhitungan biaya investasi merupakan aktivitas yang dilakukan untuk menempatkan dana pada suatu periode tertentu dengan harapan penggunaan dana tersebut bisa menghasilkan keuntungan dan peningkatan 
nilai investasi bagi pihak perusahan. Adapun investasi yang dilakukan pihak PT. $X$ adalah penambahan jalur pipa, penambahan jalur pipa yang dilakukan dari tangki darat sampai dermaga dengan jarak $1.248 \mathrm{~m}$ sampai 1.790 meter, dengan diameter ukuran pipa 10 inchi. Berikut ini merupakan perhitungan biaya investasi yang dilakukan oleh pihak PT. X sebagai berikut:

Tabel 8. Perhitungan Biaya

\begin{tabular}{|c|c|c|c|c|c|}
\hline No & $\begin{array}{c}\text { Ukuran } \\
\text { Pipa } \\
\text { (inchi) }\end{array}$ & $\begin{array}{c}\text { Material } \\
\text { Pipa }\end{array}$ & $\begin{array}{c}\text { Nama } \\
\text { Jalur } \\
\text { Pipa }\end{array}$ & $\begin{array}{c}\text { Panjang } \\
\text { (m) }\end{array}$ & $\begin{array}{c}\text { Biaya } \\
\text { (US\$) }\end{array}$ \\
\hline 1 & $10 "$ & $\begin{array}{c}\text { Carbon } \\
\text { Steel }\end{array}$ & B1 & 1.790 & $30.430,00$ \\
\hline 2 & $10 "$ & $\begin{array}{c}\text { Carbon } \\
\text { Steel }\end{array}$ & B2 & 1.646 & $27.982,00$ \\
\hline 3 & $10 "$ & $\begin{array}{c}\text { Carbon } \\
\text { Steel }\end{array}$ & B3 & 1.448 & $24.616,00$ \\
\hline 4 & $10 "$ & $\begin{array}{c}\text { Carbon } \\
\text { Steel }\end{array}$ & B4 & 1.248 & $21.216,00$ \\
\hline \multicolumn{5}{|c|}{ Total Biaya } & $104.244,00$ \\
\hline
\end{tabular}

Berdasarkan Tabel 8 menunjukkan bahwa total biaya investasi yang dikeluarkan pihak PT. $X$ sebesar 104.244,00 US\$. Dari perhitungan yang dilakukan untuk investasi pembangunan jalur pipa tersebut, dapat dilakukan evaluasi kembali kepada pihak PT. X. untuk menghindar terjadinya kesalahan melakukan investasi, serta mengalami kerugian bagi PT. $X$.

\section{Simpulan}

Berdasarkan hasil simulasi yang telah dilakukan dengan menggunakan software Extandsim bahwa model perbaikan yang telah dirancang menghasilkan dua alternatif. Kemudian dilakukan running model simulasi sebanyak 8 kali replikasi, sehingga pada alternatif pertama menghasilkan jumlah output atau jumlah kapal terlayani yaitu 263 kapal, sedangkan pada alternatif kedua menghasilkan jumlah output atau jumlah kapal terlayani yaitu $489 \mathrm{kapal}$, dan pada output model awal sebesar 278 kapal. Melihat perbandingan antara output awal, output alternatif pertama dan output alternatif kedua, maka output alternatif kedua memiliki tingkat kapal yang terlayani terbanyak dari output awal amaupun output alternatif pertama. Sehingga dapat simpulkan bahwa pada alternatif kedua sudah memiliki tingkat pelayanan yang optimal, serta telah meminimasi antrian kapal di kolam labuh dan memperkecil waktu tunggu kapal di kolam labuh.

\section{Daftar Pustaka}

Ahmad, Aulia \& Muhammad Mashuri. Analisis Sistem Antrian Kapal Pengangkut Barang di Pelabuhan Tanjung Perak Surabaya. Jurnal Sains Dan Seni ITS Vol. 5, No.1, (2016) 2337-3520 (2301-928X Print).

Banks, J., Carson, J. S., Nelson, B. L. \& Nicol, D. M. (2005). Discrete-Event System Simulation Fourth Edition. New Jersey: Pearson.

ExtandSim. (2017). ExtandSim User's Guide. San Jose, USA. Imagine That Inc.

Halim, Gharta Hadisa.Teori Antrian (Queueing Theory). Makalah II 2092 Probabilitas dan Statistik - Sem. I Tahun 2010/2011.

Manik, Bramson P. Analisis Kelayakan Panjang Dermaga Curah Cair Berdasarkan Data Kunjungan Kapal Di Pelabuhan Dumai. Jom Fteknik Volume 3 No.2 Oktober 2016.

Menteri Perhubungan Republik Indonesia. (2017). Peraturan Menteri Perhubungan Republik Indonesia Nomor Pm 72 Tahun 2017 Tentang Jenis, Struktur, Golongan Dan Mekanisme Penetapan Tarif Jasa Kepelabuhanan. Jakarta.

Montgomery, C. D. \& Runger, C. G. (2003). Applied Statistics and Probability for Engineers Third Edition. New York: John Wiley \& sons, Inc.

Pratama, Yoga. Aplikasi Statistical Process Control DalamPengendalian Kadar Asam Lemak Bebas (ALB) Dan Bilangan Peroksida Produk RBDPO Di Pt Asianagro. Skripsi Fakultas Teknologi Pertanian, Institut Pertanian Bogor. Bogor. 2007.

Sentia, Prima Denny. Pendekatan Simulasi Untuk Analisis Antrian Pada Bengkel Servis PT. X. ISSN 2088-4842 / 2442-8795 Optimasi Sistem Industri. 2016.

Soepeno, B. (1997). Statistik Terapan. Jakarta: Rineka Cipta.

Sutini, dkk. Analisis Biaya Bongkar Muat Saat Kapal Memasuki Alur Masuk Pelabuhan Tanjung Emas Semarang Jurnal Saintek Maritim, Volume XVII Nomer 1, September 2017, ISSN: 1412-6826.

Walpole, R. E. (1992). Pengantar Statistik Edisi Ketiga. Jakarta: PT. Gramedeia Pustaka Utama.

Wibowo, Harmaini. Analisis Faktor - Faktor Yang Mempengaruhi Waktu Tunggu Kapal Di Pelabuhan Tanjung Emas Semarang. 
DOI: https://doi.org/10.26593/jrsi.v8i2.3223.113-120

Tesis, Universitas Diponegoro Program Pascasarjana Magister Teknik Sipil. 2010.

Wiley, John \& Sons Ltd. System Modelling

Theory and Practice British Library Cataloguing in Publication Data. England. 2004. 